\title{
Free tropospheric ozone changes over Europe as observed at Jungfraujoch (1990-2008): An analysis based on backward trajectories
}

\author{
J. Cui, ${ }^{1}$ S. Pandey Deolal, ${ }^{1}$ M. Sprenger, ${ }^{1}$ S. Henne, ${ }^{2}$ J. Staehelin, ${ }^{1}$ M. Steinbacher, ${ }^{2}$ \\ and P. Nédélec ${ }^{3}$ \\ Received 7 October 2010; revised 21 February 2011; accepted 8 March 2011; published 24 May 2011.
}

[1] High-altitude ozone measurements at the Jungfraujoch observatory, Switzerland (JFJ, 3850 asl), covering the period 1990-2008 are investigated in this study. Anthropogenic ozone precursor emissions decreased over Europe and North America since the early 1990s. However, ozone concentrations at JFJ over the 19 year period show significant positive trends in the 1990s and no significant trends after 1999. Ozone trends were further studied with respect to air mass origin using 20 day back trajectories. The ozone increase during winter was particularly large in air masses with recent contact with the European planetary boundary layer (PBL), most probably in response to the steady decrease in European NO emissions leading to less ozone titration. On the other hand, the corresponding summer ozone increase was small, possibly attributable to the balancing effects of decreasing European ozone precursor emissions and increasing baseline ozone concentrations. Ozone from all source regions other than European PBL has a similar temporal pattern, exhibiting an increase for about the first 10 years, then leveling off to either no trend or insignificant decrease. This suggests that the physical processes determining the trend are beyond the time scale of the used backward trajectories or not described adequately by the simplified transport description in individual trajectories.

Citation: Cui, J., S. Pandey Deolal, M. Sprenger, S. Henne, J. Staehelin, M. Steinbacher, and P. Nédélec (2011), Free tropospheric ozone changes over Europe as observed at Jungfraujoch (1990-2008): An analysis based on backward trajectories, J. Geophys. Res., 116, D10304, doi:10.1029/2010JD015154.

\section{Introduction}

[2] In this paper we study the long-term evolution of surface ozone measured at the high alpine observatory Jungfraujoch (JFJ, Switzerland) in 1990-2008. Ozone concentrations at JFJ increased as first documented by Brönnimann et al. [2002]. Ordónez [2006] and recently Gilge et al. [2010] reported significant upward trends at three elevated high mountain sites in Europe, namely JFJ, Zugspitze (Germany) and Sonnblick (Austria) during the periods 1992-2002 and 1995-2007, respectively.

[3] Tropospheric ozone concentrations result from complex interactions between (1) transport from the stratosphere [e.g., Junge, 1962; Danielsen, 1968], (2) in situ photochemical production caused by the oxidation of volatile organic compounds (VOCs) and carbon monoxide (CO) in the presence of nitrogen oxides $\left(\mathrm{NO}_{\mathrm{x}}=\mathrm{NO}+\mathrm{NO}_{2}\right)$ [e.g., Levy, 1971;

\footnotetext{
${ }^{1}$ Institute for Atmospheric and Climate Science, ETH Zürich, Zurich, Switzerland.

${ }^{2}$ Empa, Swiss Federal Laboratories for Materials Science and Technology, Dübendorf, Switzerland.

${ }^{3}$ Laboratoire d'Aérologie, Centre National de la Recherche Scientifique, Toulouse, France.

Copyright 2011 by the American Geophysical Union. 0148-0227/11/2010JD015154
}

Crutzen, 1974], (3) photochemical ozone destruction when $\mathrm{NO}_{\mathrm{x}}$ concentrations are very low and (4) dry deposition. Changes in anthropogenic emissions of ozone precursors can alter the tropospheric ozone concentration, as well as its diurnal and seasonal variations [e.g., Staehelin et al., 1994]. Many studies have documented tropospheric long-term ozone changes and trends based on measurements at various sites and in different periods [e.g., Logan, 1994; Logan et al., 1999; Oltmans et al., 1998, 2006; TOR-2, 2003; Vingarzan, 2004; Tarasova et al., 2009]. Long-term tropospheric ozone measurements from Europe show a significant increase in ozone concentrations from the 1950 s to the end of the 1980s which is commonly attributed to the rapid economic growth accompanied by growing anthropogenic $\mathrm{NO}_{\mathrm{x}}$ and VOC emissions [e.g., Staehelin et al., 1994; Logan et al., 1999; Oltmans et al., 1998; Parrish et al., 2009]. However, since the late $1980 \mathrm{~s}$, various control strategies have been implemented in Europe leading to a considerable reduction of anthropogenic ozone precursor emissions $\left(-39 \%\right.$ for $\mathrm{NO}_{\mathrm{x}}$ and $-51 \%$ for nonmethane VOCs for EU-27 in the period 1990-2008 [European Environment Agency (EEA), 2010]). The decrease in $\mathrm{NO}_{\mathrm{x}}$ emission caused increasing winter ozone concentrations due to less titration by NO [Lindskog et al., 2001] at many (urban) sites in Europe [e.g., Ordóñez et al., 2005; Brönnimann et al., 2002]. The decrease in European emissions has induced a decrease in ozone peaks 


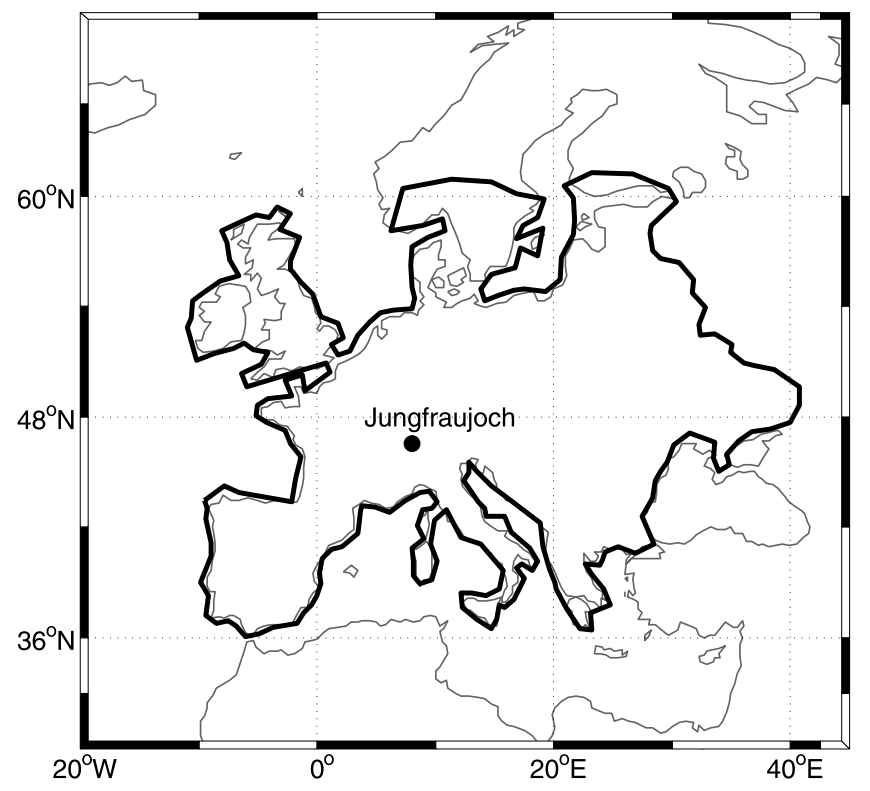

Figure 1. Map showing the location of Jungfraujoch (black dot) and domain of European PBL (circled as thick black polygon) used in backward trajectory analysis.

in summer as for example reported from the UK [Derwent et al., 2003] and several sites in Switzerland [Brönnimann et al., 2002]. However, only small decreasing trends of ozone or even increases were found at rural sites in Switzerland despite of large decrease in its precursors [Kuebler et al., 2001; Brönnimann et al., 2000, 2002; Pochanart et al., 2001; Ordónez et al., 2005]. Evidently, the significant decrease in European ozone precursor emissions cannot explain the increase of surface ozone at JFJ during the 1990s. A similar conclusion is also drawn by Gilge et al. [2010] who reported that the observed positive ozone trend at JFJ and other elevated sites in the Alps over the last 15 years could not be consistently explained neither by horizontal advection (i.e., no dependence on wind direction) nor by changes in ozone precursor concentrations nor in changes in the vertical transport from the boundary layer.

[4] The lifetime of tropospheric ozone varies from days to months, and the lifetimes of its precursors span an even larger range, enabling the transport of ozone and its precursors on intercontinental scales. It has been well documented that the polluted air from the American planetary boundary layer (PBL) can be exported to the free troposphere by convection and warm conveyor belts and subsequently transported to Europe [Stohl and Trickl, 1999; Huntrieser et al., 2005; Li et al., 2005]. Emissions of $\mathrm{NO}_{\mathrm{x}}$ in the United States (US) decreased by $35 \%$ and VOCs emissions decreased by $31 \%$ between 1980 and 2009 [U.S. Environmental Protection Agency, 2009]. Increasing trends of ozone on the west coast of North America from 1987 to present were reported [Jaffe and Ray, 2007; Parrish et al., 2009]. However, Lefohn et al. [2010], applying different statistical methods and exposure metrics, reported different results. The authors demonstrated changes in trending rates over time and suggested that future research should quantify changing rates using multiyear trending over the period of record (e.g., 15 year moving trends). Cooper et al. [2010] found a strong increase in springtime free tropospheric ozone concentrations during 1985-2008 that might be attributed to rising Asian precursor emissions. In contrast to North America, ozone precursor emissions in Asia have increased substantially since the 1990s because of rapid industrialization [Streets et al., 2001; Zhang et al., 2007]. However, there is no consensus on how much the emissions from Asia influence the European background ozone concentration [Auvray and Bey, 2005; Balzani Lööv et al., 2008].

[5] Large increases in upper troposphere (UT)/lower stratosphere (LS) ozone were deduced from regular aircraft measurements of the program MOZAIC (Measurements of OZone and water vapor by in-service AIrbus airCraft) [Thouret et al., 2006; Zbinden et al., 2006], showing an increasing rate of about $1 \% / \mathrm{yr}$ in the UT and about $1.5 \% / \mathrm{yr}$ in the LS over the North Atlantic for the period 1994-2003. Lowermost stratospheric ozone reached minimum concentrations in 1992 at the northern midlatitudes, commonly attributed to the Mount Pinatubo eruption which decreased stratospheric ozone on a hemispheric scale [World Meteorological Organization, 2003]. This is also reflected in total ozone time series showing minimum values in 1992-1993 and a subsequent increase in the northern hemisphere [e.g., Staehelin et al., 2001; World Meteorological Organization, 2003]. Ordóñez et al. [2007] presented evidence that positive ozone trends over Europe during the 1990s might be attributable to a large extent to increasing ozone levels in the lowermost stratosphere that occurred after 1992.

[6] In order to identify the possible drivers of the long-term evolution of ozone at JFJ, we apply a backward trajectory analysis as used in previous studies [e.g., Balzani Lööv et al., 2008; Cui et al., 2009]. The Lagrangian trajectory tool LAGRANTO [Wernli and Davies, 1997] is used to calculate 20 day backward trajectories to identify transport and origin of air arriving at JFJ. Individual source regions are identified to study variability in concentrations of ozone as observed at JFJ. Based on these analyses, we discuss the noticeable increase in ozone over Europe that took place during the 1990s. The ozone data set and model concept are described in section 2. By the use of the trajectory analysis, we classify ozone measured at JFJ into European PBL ozone and baseline ozone (baseline ozone is defined as air composition not recently affected by local and regional emissions), and validate this classification in section 3. In addition, we identify the air origins in terms of individual source regions and analyze ozone features accordingly and section 4 contains conclusions.

\section{Data and Methods}

\subsection{Measurements}

[7] The high-altitude observatory at Jungfraujoch (JFJ) is located in the Swiss Alps $\left(46.55^{\circ} \mathrm{N}, 7.98^{\circ} \mathrm{E}\right.$, Sphinx observatory: $3580 \mathrm{~m}$ above sea level (asl))(see Figure 1). The site is mostly exposed to the free troposphere but, especially during the summer month, is intermittently influenced by vertically exported more polluted European planetary boundary air (PBL) [Zellweger et al., 2003]. The area influencing JFJ was recently compared with other European baseline monitoring sites and the site was categorized as "mostly remote" [Henne et al., 2010], confirming the sporadic influence of recent emissions. Measurements at JFJ were often used in the past to 
advance our understanding of chemical and photochemical processes controlling ozone in the lower free troposphere [e.g., Zanis et al., 1999, 2007; Henne et al., 2005].

[8] Trace gas measurements at JFJ are performed within the Swiss Air Pollution Monitoring Network (NABEL) and as part of the Global Atmosphere Watch (GAW) program of the World Meteorological Organization (WMO). Meteorological parameters (wind speed and direction, temperature, relative humidity) are measured operationally by the National Swiss Weather Service (MeteoSwiss). The methods used for chemical trace gas measurements are described by Zellweger et al. [2000]. In our study, measurements of $\mathrm{O}_{3}$ covering the period from 1990 to 2008 and CO covering the period 19962008 were used. Detailed information on calibration and quality control measures are described by Gilge et al. [2010]. Zanis et al. [1999] studied data quality of ozone. They reported a break in the series in 1989 probably caused by instrumental problems whereas the inhomogeneity in 1991 is probably attributable to natural variability. Measurement data were 3-hourly centrally averaged at 0000, 0600, 1200 and 1800 UTC, and are analyzed seasonally. For data analysis we used simple linear regression and confidence intervals with error probability of $5 \%$.

\subsection{Trajectory Calculations}

[9] An ensemble of 20 day backward trajectories initialized at the coordinates of JFJ were calculated for every $6 \mathrm{~h}$ over the period from 1990 to 2008 using LAGRANTO [Wernli and Davies, 1997]. The model is driven by 6-hourly wind fields from the homogenized ECMWF ERA-Interim reanalyses data set [Berrisford et al., 2009]. The ECMWF model fields are interpolated onto a latitude/longitude grid with horizontal resolution of $1^{\circ} \times 1^{\circ}$ and 61 vertical hybrid levels. Each trajectory ensemble consists of one reference trajectory centered at JFJ with pressure level of $650 \mathrm{hPa}$ representing the real pressure level of JFJ, four trajectories horizontally displaced by $0.5^{\circ}$ and two trajectories vertically displaced by $10 \mathrm{hPa}$. We are aware that the real altitude of JFJ is much higher than the ECMWF model topography and that different initial altitudes and meteorological input data could be used for backward trajectory analysis at JFJ. Our approach was selected because we are interested in both long-range transport and continental-scale transport. For each day, four trajectory ensembles with arriving time at 0000, 0600, 1200 and 1800 UTC were calculated. Along the trajectories 6-hourly values of longitude, latitude, altitude (in pressure), potential vorticity (PV), surface pressure are retrieved. In addition, planetary boundary layer height $(\mathrm{BLH})$ is retrieved from the ERA-Interim 6-hourly forecast and is also attached to the trajectory. In this study, the extratropical dynamical tropopause is defined as the $2 \mathrm{PV}$ unit (PVU) isosurface. Additionally, regions with $\mathrm{PV} \geq 2 \mathrm{PVU}$ below $500 \mathrm{hPa}$ are treated as troposphere to exclude diabatically generated high-PV regions mimicking stratospheric PV values.

\subsection{Partitioning Into Different Source Regions}

[10] In order to distinguish between baseline air mass $\left(\mathrm{R}_{\mathrm{b}}\right)$ and European PBL air mass $\left(\mathrm{R}_{\mathrm{EU}}\right)$, the following procedure was applied to every 20 day trajectory ensemble to accomplish the data partitioning. A measurement $C_{m}$ at a certain time $m$ was attributed to $\mathrm{R}_{\mathrm{b}}$ if the total residence time of the corresponding trajectory ensemble in the European PBL was zero, i.e., if the residence time of all seven trajectory members within the European PBL equals zero, meaning neither reference nor displaced trajectories of the air parcel had contact with European PBL during the previous 20 days. Formally, this can be expressed as

$$
C_{m} \in R_{b} \quad \text { if } \quad \sum_{i=1}^{7} T_{m}^{i}=0 .
$$

[11] $T_{m}^{i}$ is the residence time within the European PBL domain of the $i$ th trajectory of the $C_{m}$ associated ensemble (Figure 1). We assume a trajectory to reside within the PBL if the altitude of the trajectory is below the corresponding grid box BLH. The remaining data were assigned into the class $R_{E U}$, which contains the air masses under the influence of European emissions. Note that the applied criterion intends to rigorously select baseline air, which has no influence from European emissions.

[12] As a further refinement, the class $R_{b}$ is subdivided into several classes in term of a more distant source region of the air parcel. For the trajectories with contact with several source regions, only the most recent contact, meaning the shortest time span between the contact and the arrival at JFJ, is considered. To determine air masses that had stratospheric origin (class $\mathrm{R}_{\mathrm{SI}}$ ), the dynamical tropopause is used. $\mathrm{R}_{\mathrm{NA}}, \mathrm{R}_{\mathrm{AS}}, \mathrm{R}_{\mathrm{AF}}$ and $\mathrm{R}_{\mathrm{MBL}}$ data are defined in an analogous way, representing the air masses under the most recent influence of the PBL of North America, Asia, Africa and the marine boundary layer (MBL), respectively. If the air in its 20 day backward history remains always in the free troposphere (FT), it is tagged as a separate class, namely $\mathrm{R}_{\mathrm{FT}}$.

\section{Results and Discussion}

\subsection{Changes in Ozone During 1990-2008}

[13] Ozone mean concentrations at JFJ are shown in Figure 2 for the individual seasons from 1990 to 2008. Positive ozone trends were found when considering the 19 year period with maximum of $+0.49 \pm 0.17 \mathrm{ppb} / \mathrm{yr}$ in winter and minimum of $+0.22 \pm 0.28 \mathrm{ppb} / \mathrm{yr}$ in summer in accordance with Ordónez et al. [2007], who analyzed ozone data from 1992 to 2004 using three elevated mountain sites including $\mathrm{JFJ}$; they reported ozone trends of $+0.53 \pm 0.25 \mathrm{ppb} / \mathrm{yr}$ in winter and $+0.19 \pm 0.48 \mathrm{ppb} / \mathrm{yr}$ in summer. When considering only the period 1990-1999, the positive trends of ozone are greater for all seasons (with maximum $0.99 \pm 0.46 \mathrm{ppb} / \mathrm{yr}$ in winter and minimum $0.69 \pm 0.80 \mathrm{ppb} / \mathrm{yr}$ in summer). The trending patterns shift at the end of 1990s. For instance, ozone trends over the period 2000-2008 become negative (statistical insignificant). This indicates that the increase of ozone leveled off since the end of 1990s, although the shortness of the time period and the considerable interannual variability prohibits a conclusive statistically significant assessment.

[14] In order to illustrate this change, we applied linear trends with moving 10 year time periods. In winter, statistically significant positive trends were found for the first seven 10 year periods (from 1990-1999 to 1996-2005), positive trends but statistically insignificant for 1997-2006 and 19982007, and slightly negative insignificant trend for 1999-2008 (see Figure 3); in summer, the positive ozone trends are all 


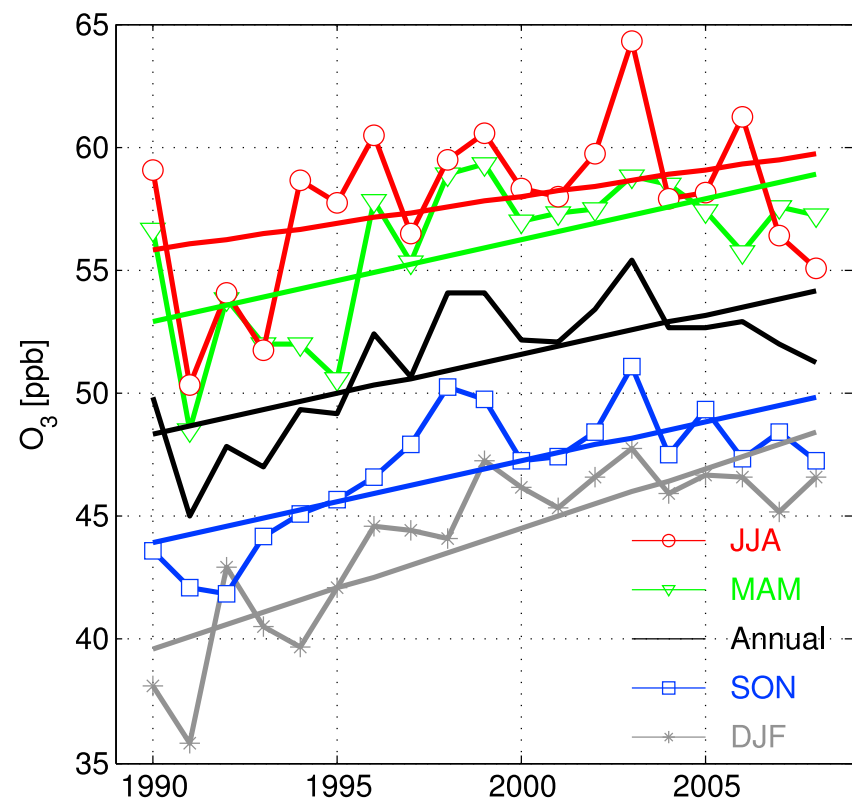

Figure 2. Time series of surface ozone measurements at Jungfraujoch in 1990-2008 (annual and seasonal mean values). Annual (black): $0.32 \pm 0.18 \mathrm{ppb} / \mathrm{yr}$; DecemberJanuary-February (DJF, grey): $0.49 \pm 0.17 \mathrm{ppb} / \mathrm{yr}$; March-April-May (MAM, green): $0.33 \pm 0.22 \mathrm{ppb} / \mathrm{yr}$; JuneJuly-August (JJA, red): $0.22 \pm 0.28 \mathrm{ppb} / \mathrm{yr}$; and SeptemberOctober-November (SON, blue): $0.33 \pm 0.16 \mathrm{ppb} / \mathrm{yr}$.

statistically insignificant except for 1991-2000 and negative trends occurred for 1998-2007 and 1999-2008.

[15] The increase in ozone in the 1990s is likely also associated with the following processes. The negative anomalies in 1992-1993 are coincident with low stratospheric ozone values caused by the 1991 eruption of Mount Pinatubo [Angell, 1997]. Ozone mean concentrations that are particu- larly high in 1998-1999 might be linked to specific dynamic conditions which are in favor of long-range transport of Asian pollution [Koumoutsaris et al., 2008]. The ozone anomaly in summer and fall 2003 was most likely caused by the anomalously hot and dry summer in western and central Europe [Ordónez et al., 2007]. Summer 2006 was very warm too, probably explaining high summer values.

[16] Figure 4 shows the ozone frequencies in three different periods: 1990-1995, 1996-2001 and 2002-2008. The most pronounced feature is an upward shift in the occurrence of relatively high ozone mixing ratios. In all seasons, there is an upward shift in the frequency of ozone concentrations from lower range to higher range from the first period to the second period, but no change thereafter. The changing patterns in frequency of the ozone concentrations from the lower range to the higher range implies that either baseline concentrations are increasing or European local air is affecting the change or both are contributing to the change.

\subsection{Ozone and Carbon Monoxide in Baseline Air and European PBL Air}

[17] As described in section 2.3, the measurement data were split into a class with recent contact with European PBL $\left(\mathrm{R}_{\mathrm{EU}}\right)$ and one without such contact, named baseline $\left(\mathrm{R}_{\mathrm{b}}\right)$. The JFJ station measures more frequently free tropospheric air in the colder seasons than in the warm ones (see Table 1). The separation between these two classes in all seasons is statistically significant in term of Mann-Whitney-U text (see Table 1). The results herein only represent an upper estimation of undisturbed cases since the trajectories do not resolve small-scale flows that are particularly important in summer (compare auxiliary material). ${ }^{1}$ Figure 5 shows the interannual changes in the frequency of the two classes. During winter,

${ }^{1}$ Auxiliary materials are available in the HTML. doi:10.1029/ 2010JD015154.

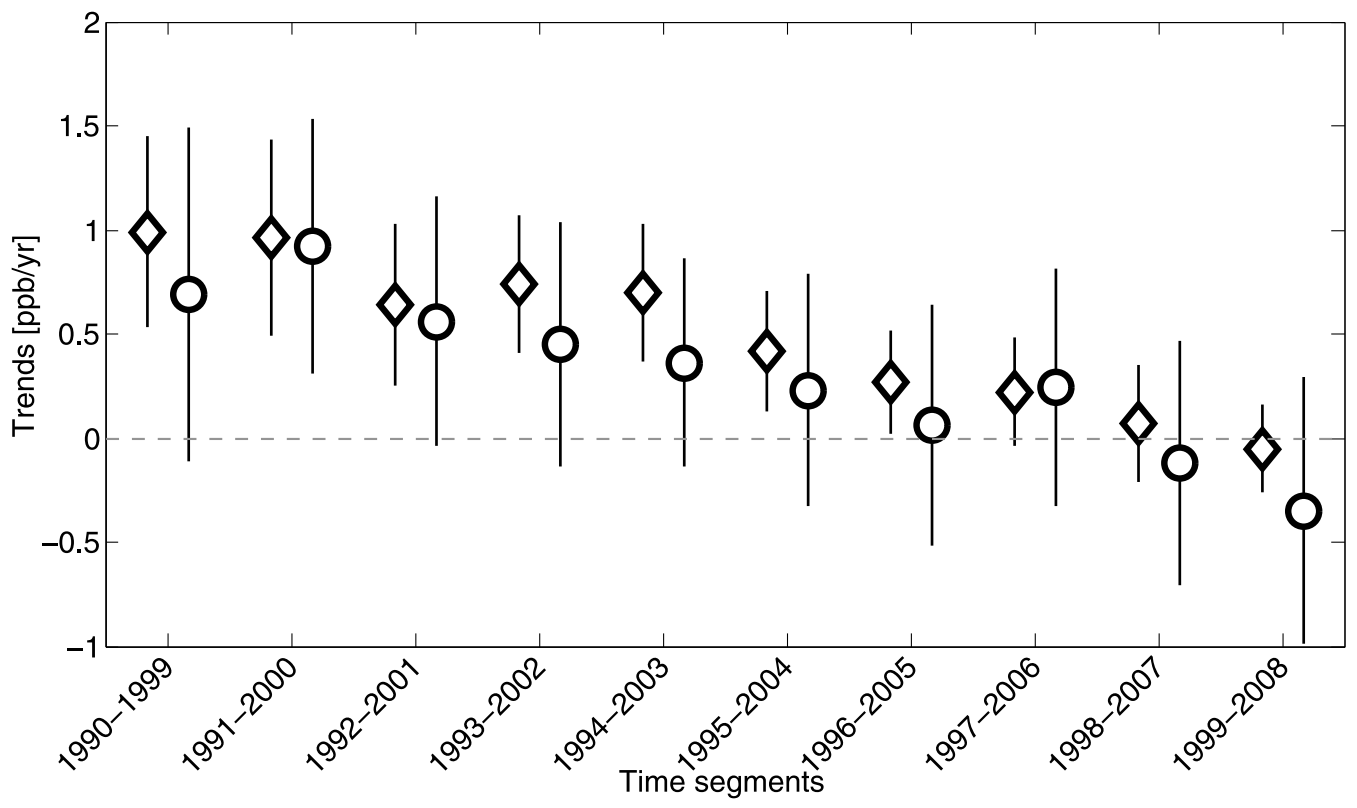

Figure 3. Linear trends of moving 10 year periods in winter (diamonds) and summer (circles) for ozone at Jungfraujoch. Vertical lines show 95\% confidence intervals. 


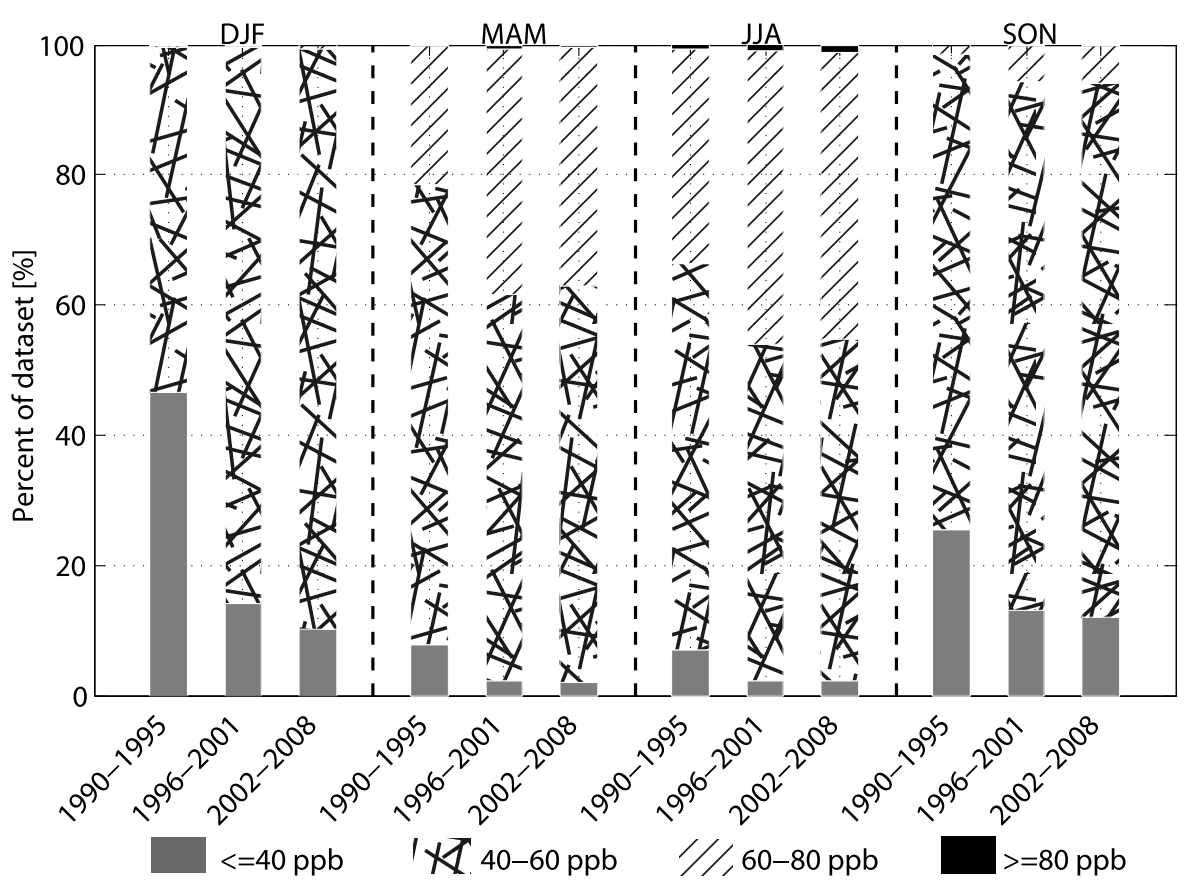

Figure 4. Frequencies of ozone mixing ratios of Jungfraujoch for three periods: 1990-1995, 1996-2001, and 2002-2008.

JFJ is mostly exposed to the lower free troposphere, whereas the fraction of free tropospheric air decreases from fall to spring to summer, when the fraction of European PBL air is similar to baseline air. Figure 5 suggests an upward tendency of European PBL air fraction in winter until around 2005, implying an increase in the exposure time of JFJ to European PBL air. However, the change is not significant. In this context we also looked at changes in BLH altitude (see Annex). For evaluation of reliability of the classification into $\mathrm{R}_{\mathrm{EU}}$ and $\mathrm{R}_{\mathrm{b}}$, we compared the results of the trajectory analysis with a synoptic weather classification (see auxiliary material). The results show generally reasonable agreement for winter, whereas the differences are larger in the warmer seasons when continental-scale trajectories tend to underestimate vertical transport in complex terrain (see Figure 5).

[18] CO mean concentrations can be also used to evaluate the classification $R_{E U} / R_{b}$. The $C O$ concentrations of $R_{E U}$ are expected to be comparatively larger than those of $R_{b}$. Figure 6 (right) confirms this expectation, and additionally shows an evident decline in $\mathrm{CO}$ concentrations for both classes that is consistent with the reduction of $\mathrm{CO}$ in Europe as reported by EEA [2010]. For comparison, CO measurements at $500 \mathrm{hPa}$ at Frankfurt, Munich, Paris and New York extracted from measurements of MOZAIC were used in this study. CO concentrations measured in the free troposphere above Frankfurt, Munich, Paris and New York are usually much closer to our baseline $\mathrm{CO}$ than to the European $\mathrm{CO}$; the largest deviations are found in summer 2003 in which the heat wave might have affected the comparison.

[19] Wintertime ozone concentrations in baseline air are greater than in European PBL air (Figure 6), which is consistent with ozone loss by titration with NO and dry deposition (transport time of an air parcel from the European PBL to JFJ amounts to $>2$ days in $10 \%$ cases and $\geq 1$ day and $\leq 2$ days in $17 \%$ cases). In contrast, summertime ozone concentrations are greater in European PBL air in agreement with photochemical production from its precursors. Ozone concentrations show a rather steady increase in all seasons for both $R_{b}$ and $R_{E U}$ data in the $1990 \mathrm{~s}$, and began to level off after 2000 (Figure 6, left). In winter, the increase of ozone for $\mathrm{R}_{\mathrm{EU}}$ data can be attributed to the decrease in European NO emissions leading to less titration. In summer, no evident trend in $\mathrm{R}_{\mathrm{EU}}$ data is found if the negative anomaly in 19921994 is excluded. Because of decreases in European ozone precursor emissions, a decrease in $\mathrm{R}_{\mathrm{EU}}$ would be expected. However, in summer the convective boundary layer can reach altitudes of JFJ during high-pressure conditions (see auxiliary material), explaining high ozone concentrations in 2003 and 2006 and therefore mixing between baseline air and European PBL air can occur, which could balance the effect of a decrease from European precursor emissions.

[20] Furthermore, for the air masses belonging to the $R_{E U}$ class, the number of crossing per $1^{\circ} \times 1^{\circ}$ grid within the European domain (see Figure 1) was summed up for two

Table 1. Partitioning Ozone Data to $R_{b}$ and $R_{E U}$ and Related Ozone Features Based on Monthly Ozone Means ${ }^{\mathrm{a}}$

\begin{tabular}{|c|c|c|c|c|}
\hline \multirow{2}{*}{$\begin{array}{l}\text { Type } \\
\text { Season }\end{array}$} & \multicolumn{2}{|r|}{$\mathrm{R}_{\mathrm{b}}$} & \multicolumn{2}{|c|}{$\mathrm{R}_{\mathrm{EU}}$} \\
\hline & $\begin{array}{l}\text { Frequency } \\
(\%)\end{array}$ & $\begin{array}{c}\text { Mean } \pm 95 \% \text { CI } \\
(\mathrm{ppb})\end{array}$ & $\begin{array}{c}\text { Frequency } \\
(\%)\end{array}$ & $\begin{array}{c}\text { Mean } \pm 95 \% \mathrm{CI} \\
(\mathrm{ppb})\end{array}$ \\
\hline DJF & 79.9 & $44.52 \pm 0.96$ & 20.1 & $42.89 \pm 1.32$ \\
\hline MAM & 57.9 & $55.42 \pm 1.40$ & 42.1 & $56.58 \pm 1.36$ \\
\hline JJA & 52.4 & $55.94 \pm 1.18$ & 47.6 & $59.76 \pm 1.06$ \\
\hline SON & 70.5 & $47.11 \pm 1.14$ & 29.5 & $46.16 \pm 1.42$ \\
\hline
\end{tabular}

${ }^{\mathrm{a}}$ Data given as percentage of the total time (see section 2.3). Note that the ozone concentrations of $\mathrm{R}_{\mathrm{b}}$ and $\mathrm{R}_{\mathrm{Eu}}$ are statistically difference for the individual seasons, as can be demonstrated when applying the Mann-Whitney-U test (now shown). DJF, December-January-February; MAM, March-AprilMay; JJA, June-July-August; SON, September-October-November. 

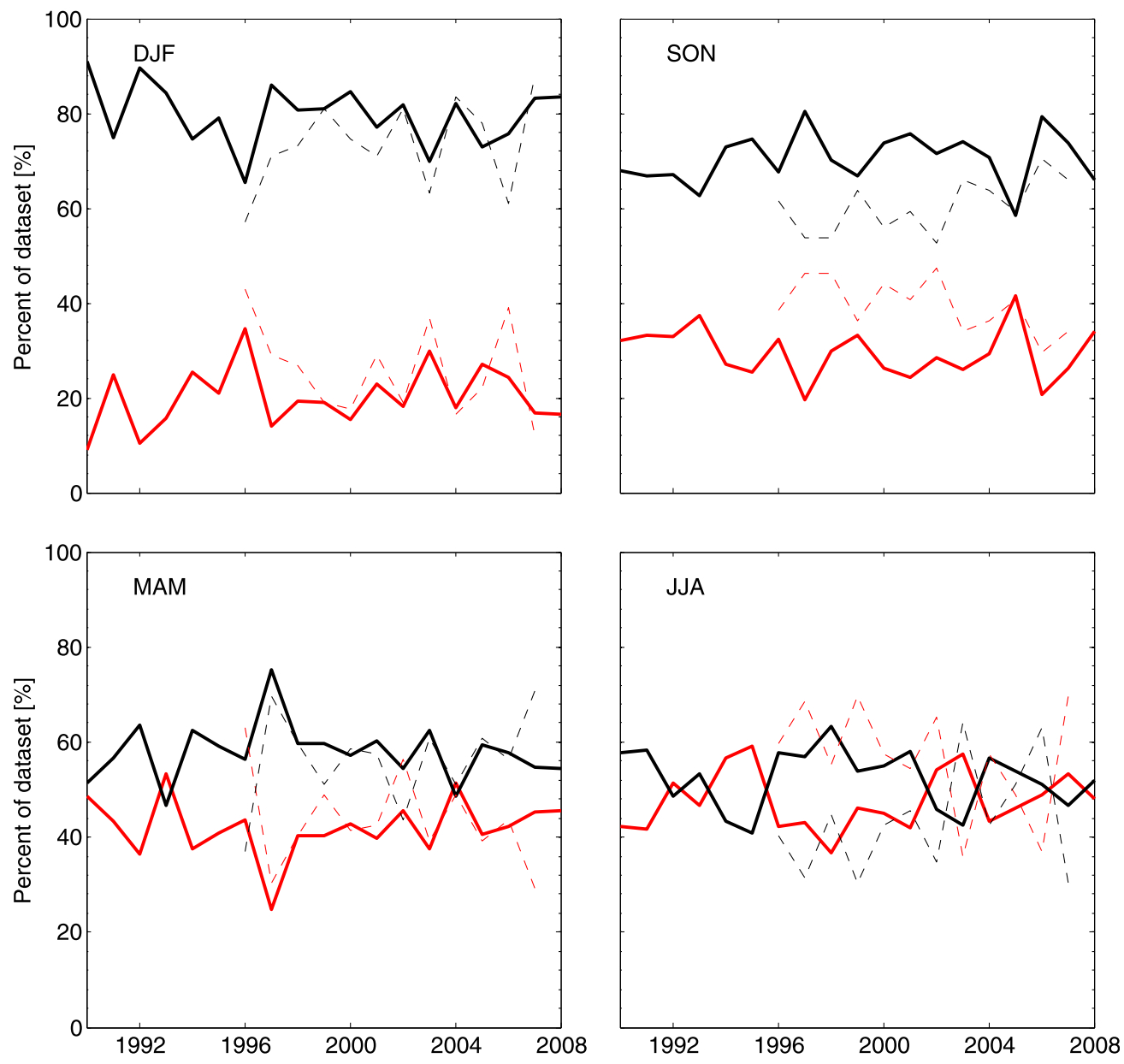

Figure 5. Interannual variations in frequency of $\mathrm{R}_{\mathrm{EU}}$ (red) and $\mathrm{R}_{\mathrm{b}}$ (black) data, derived by trajectory analysis (solid lines) and meteorological filters (dashed lines), respectively. 


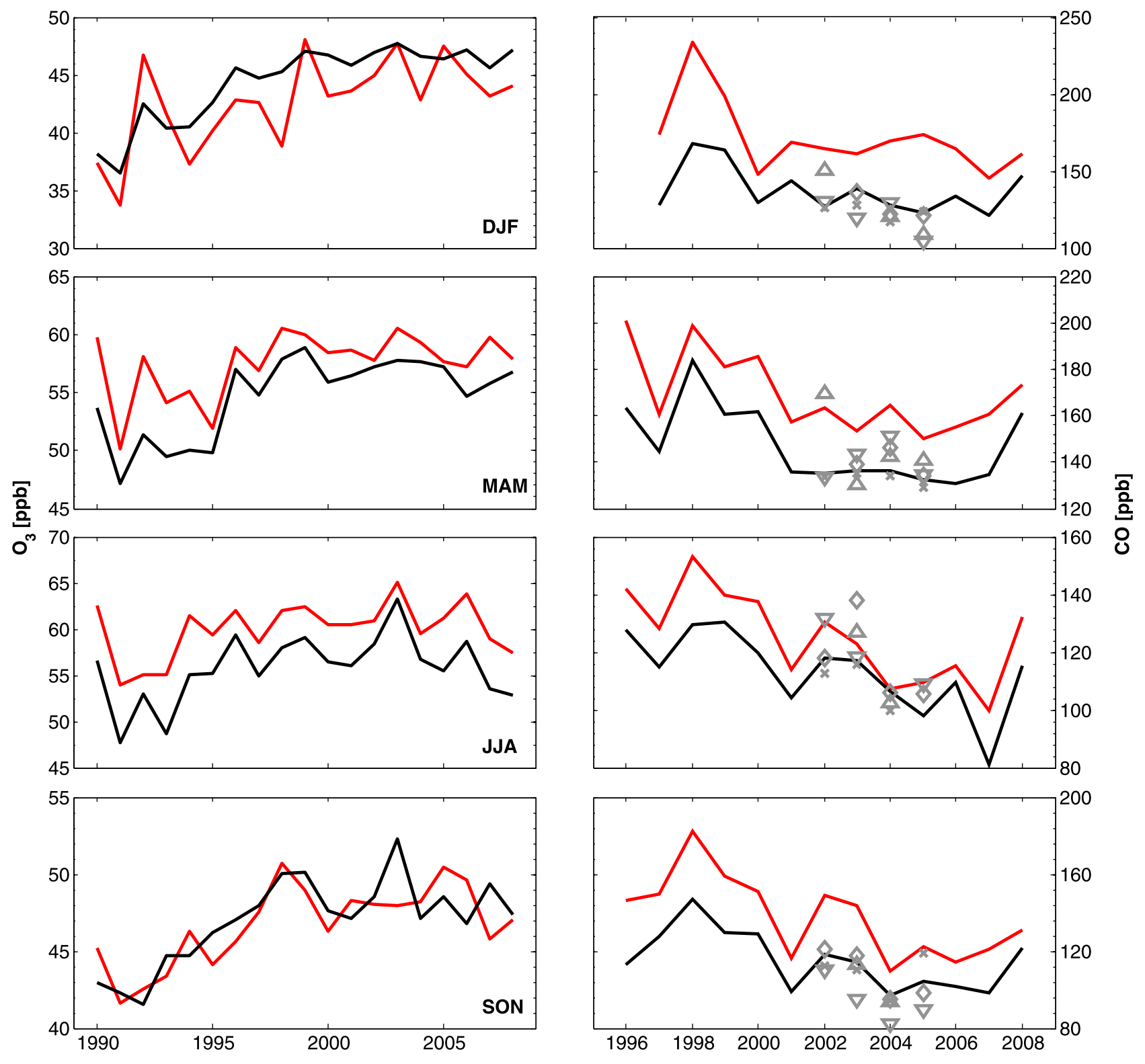

Figure 6. Time series of (left) ozone and (right) carbon monoxide at Jungfraujoch for $\mathrm{R}_{\mathrm{b}}$ (black) and $\mathrm{R}_{\mathrm{EU}}$ (red) for individual seasons. CO data derived from MOZAIC data at Frankfurt (cross), Munich (diamond), Paris (point-up triangle) and New York (point-down triangle) are also shown. 

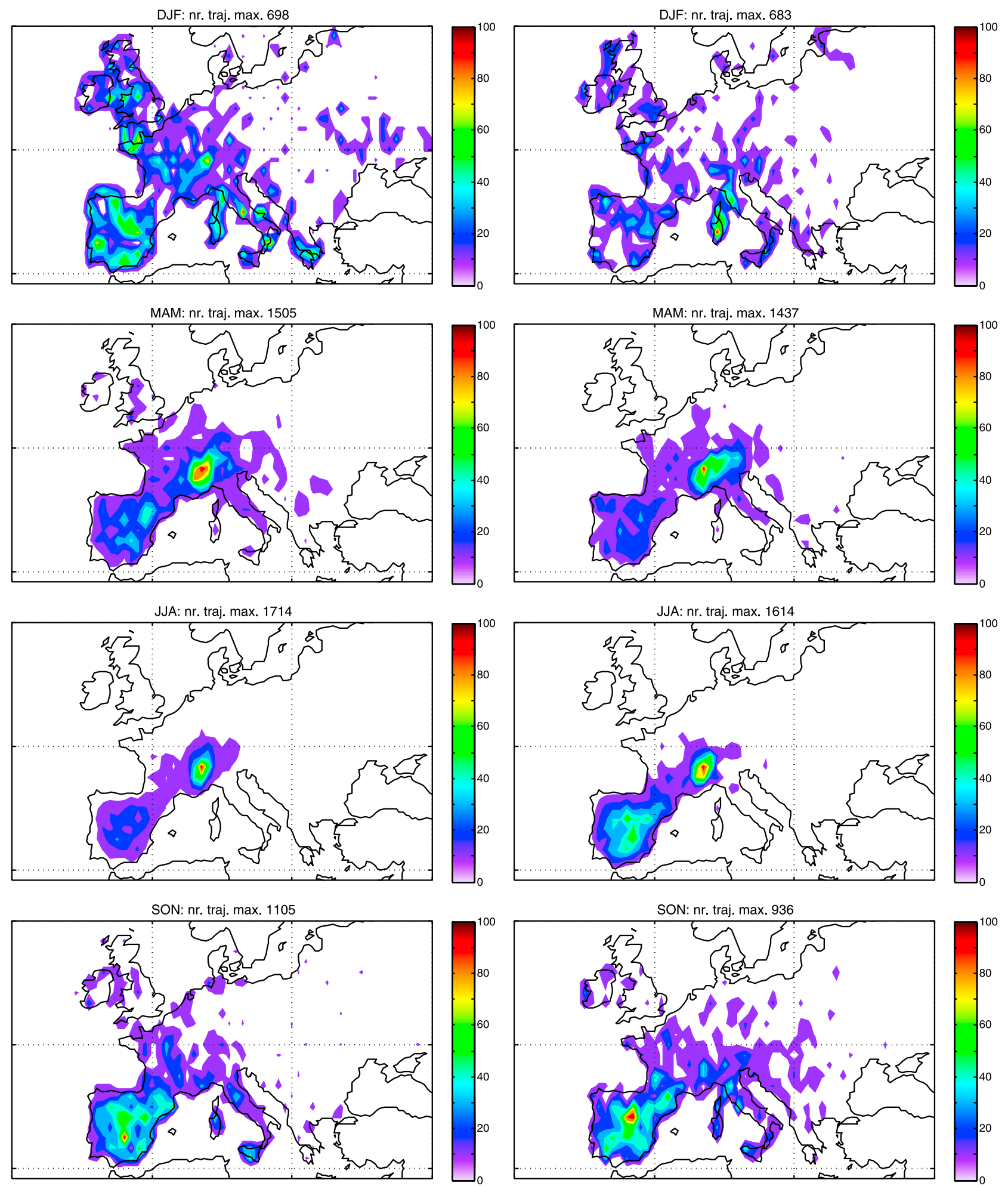

Figure 7. Footprint (\%) (indicated by colorbar) of the air mass having recent contact with European PBL (based EU domain as shown in Figure 1) during the period of (left) 1990-1999 and (right) 2000-2008 for the individual seasons. 
Table 2. Frequency (\%) of Air Masses Coming From the Individual Source Origin $^{\mathrm{a}}$

\begin{tabular}{lcccc}
\hline Class & DJF & MAM & JJA & SON \\
\hline $\mathrm{R}_{\mathrm{SI}}$ & $7.8(4.9)$ & $6.2(3.4)$ & $4.3(2.0)$ & $6.3(3.6)$ \\
$\mathrm{R}_{\mathrm{FT}}$ & $29.7(51.6)$ & $18.0(37.5)$ & $23.4(40.0)$ & $29.1(49.6)$ \\
$\mathrm{R}_{\mathrm{NA}}$ & $4.5(2.9)$ & $11.2(6.3)$ & $14.2(7.4)$ & $9.5(5.4)$ \\
$\mathrm{R}_{\mathrm{AF}}$ & $0.4(0.1)$ & $0.1(0.03)$ & $0.1(0.0)$ & $0.3(0.04)$ \\
$\mathrm{R}_{\mathrm{MBL}}$ & $26.7(18.5)$ & $13.8(9.9)$ & $4.6(3.1)$ & $14.6(10.0)$ \\
$\mathrm{R}_{\mathrm{AS}}$ & $1.3(0.01)$ & $1.2(0.03)$ & $0.3(0.0)$ & $0.9(0.06)$ \\
$\mathrm{R}_{\mathrm{EU}}$ & $20.1(15.5)$ & $42.1(36.1)$ & $47.6(44.0)$ & $29.5(23.4)$ \\
\hline
\end{tabular}

${ }^{\mathrm{a}}$ In parentheses are the frequencies when only 10 day backward trajectories would have been used.

selected time segments of 1990-1999 and 2000-2008. The crossing number per grid is then normalized to the maximum crossing number in order to obtain the frequency in percentage (\%). Figure 7 shows the geographic distribution of frequency of European PBL air advected to JFJ for the two time periods. In spring and summer, the European PBL air encountered at JFJ often originates from the surrounding Alpine area. Another dominant source area is the Iberian Peninsula, which is most important in fall. When comparing the two periods in Figure 7, we note that air parcels arriving at JFJ in winter in 1990-1999 had more frequent contact with PBL of Spain, Portugal and UK, while in 2000-2008 this source region is much less important. In contrast to winter, air masses arriving at JFJ in summer show more frequent contact with source regions of Spain and Portugal in 2000-2008 than in 1990-1999. EEA [2010] reported that anthropogenic $\mathrm{NO}_{\mathrm{x}}$ emissions in Spain in the 1990s have been increasing in contrast to most other European countries. This factor might additionally complicate the discussion of ozone changes at JFJ.

\subsection{Ozone in Individual Classes of Baseline Air}

[21] According to the method described in section 2.3, $\mathrm{R}_{\mathrm{b}}$ data were further separated into the classes of $\mathrm{R}_{\mathrm{FT}}, \mathrm{R}_{\mathrm{NA}}, \mathrm{R}_{\mathrm{SI}}$, $\mathrm{R}_{\mathrm{MBL}}, \mathrm{R}_{\mathrm{AS}}$ and $\mathrm{R}_{\mathrm{AF}}$. Table 2 indicates that in winter the class of FT was the most frequent, implying that $30 \%$ of the air masses had neither contact with PBL nor with the stratosphere within the last 20 days prior to arrival at JFJ. We used 20 day backward trajectories in order to be able to best cover intercontinental transport events. The frequency of the class FT would have been substantially larger when 10 day backward trajectories would have been used. Only approximately half of the trajectories from the North American PBL would have been detected when 10 day trajectories would have been applied.

[22] For classes with extra-European PBL contact, MBL contributes most (except in summer), followed by the North American PBL, while only a few cases were attributed to Asian PBL and African PBL. The class of $\mathrm{R}_{\mathrm{SI}}$ accounts for between $8 \%$ and $4 \%$ of the time in winter and summer, respectively. Air masses advected from the Asian PBL were often characterized by large ozone concentrations. Nevertheless, those air masses occur less than $0.5 \%$ of the time. Because of the limited frequency of air directly advected from Asian PBL and African PBL, these two classes were not treated in the further analysis.

[23] The percentile distributions for three time periods (1990-1995, 1996-2001 and 2002-2008) by classes are shown in Figure 8. The qualitative sequence of mean ozone concentrations of the different classes seems reasonable (larger ozone concentrations in air with recent contact with the stratosphere and lower ozone concentrations in clean marine air), but the differences in the mean concentrations were small. In most seasons ozone concentrations in air parcels having contact with the stratosphere were largest. However, enhancement of ozone concentrations in the air having contact with the stratosphere was small, indicating that the stratospheric air was strongly mixed with tropospheric air prior to arrival at JFJ; strong mixing with tropospheric air was also confirmed by relatively high $\mathrm{CO}$ concentrations in this class (not shown). The interannual variability in the frequency of the air masses tagged with individual source regions was considerable (see Figure 9). Air masses from FT
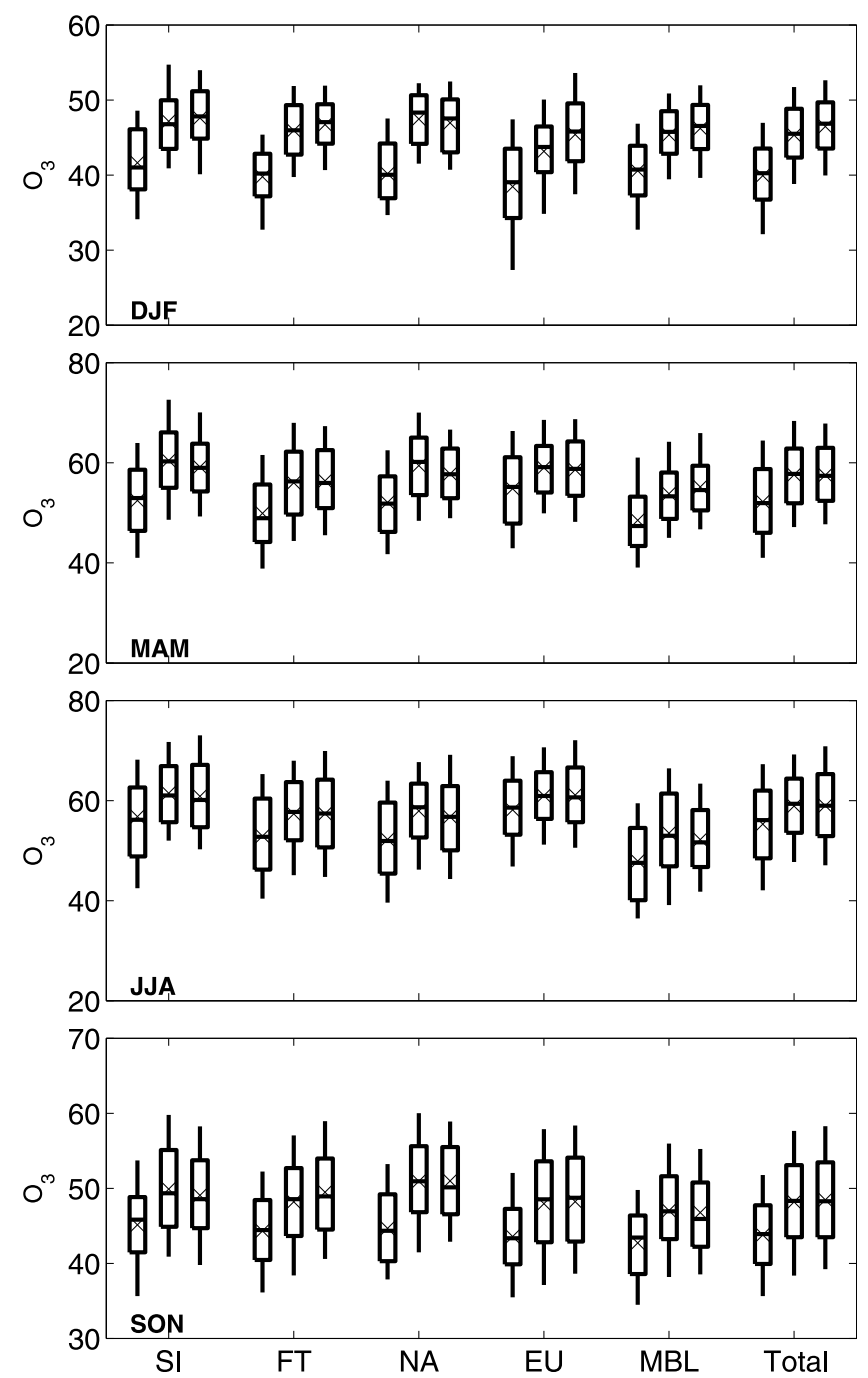

Figure 8. Ozone mean (cross), median (centerline), 25th and 75th percentile (box), 10th and 90th percentile (hinges) split by source region (see text) for three time periods: (left) 1990-1995, (middle) 1996-2001, and (right) 2002-2008. SI, stratosphere; FT, free troposphere; NA, North American PBL; EU, European PBL; MBL, marine boundary layer; Total, entire data. 

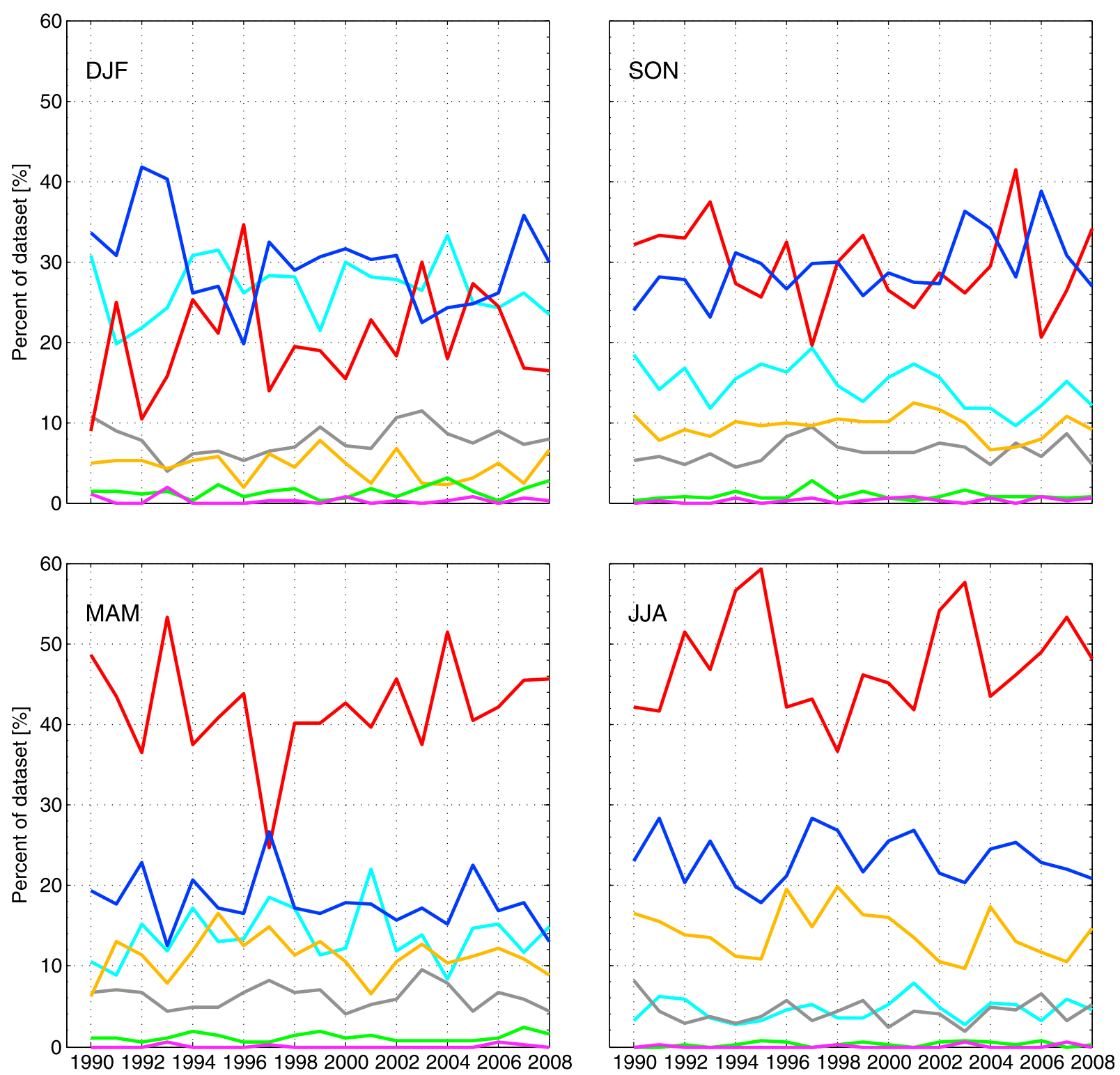

Figure 9. Interannual evolutions in frequency of JFJ air masses coming from the individual source regions. Lines: European PBL (red); free troposphere (blue); North American PBL (yellow); marine boundary layer (sky blue); stratosphere (dark grey); African PBL (magenta); and Asian PBL (green). 

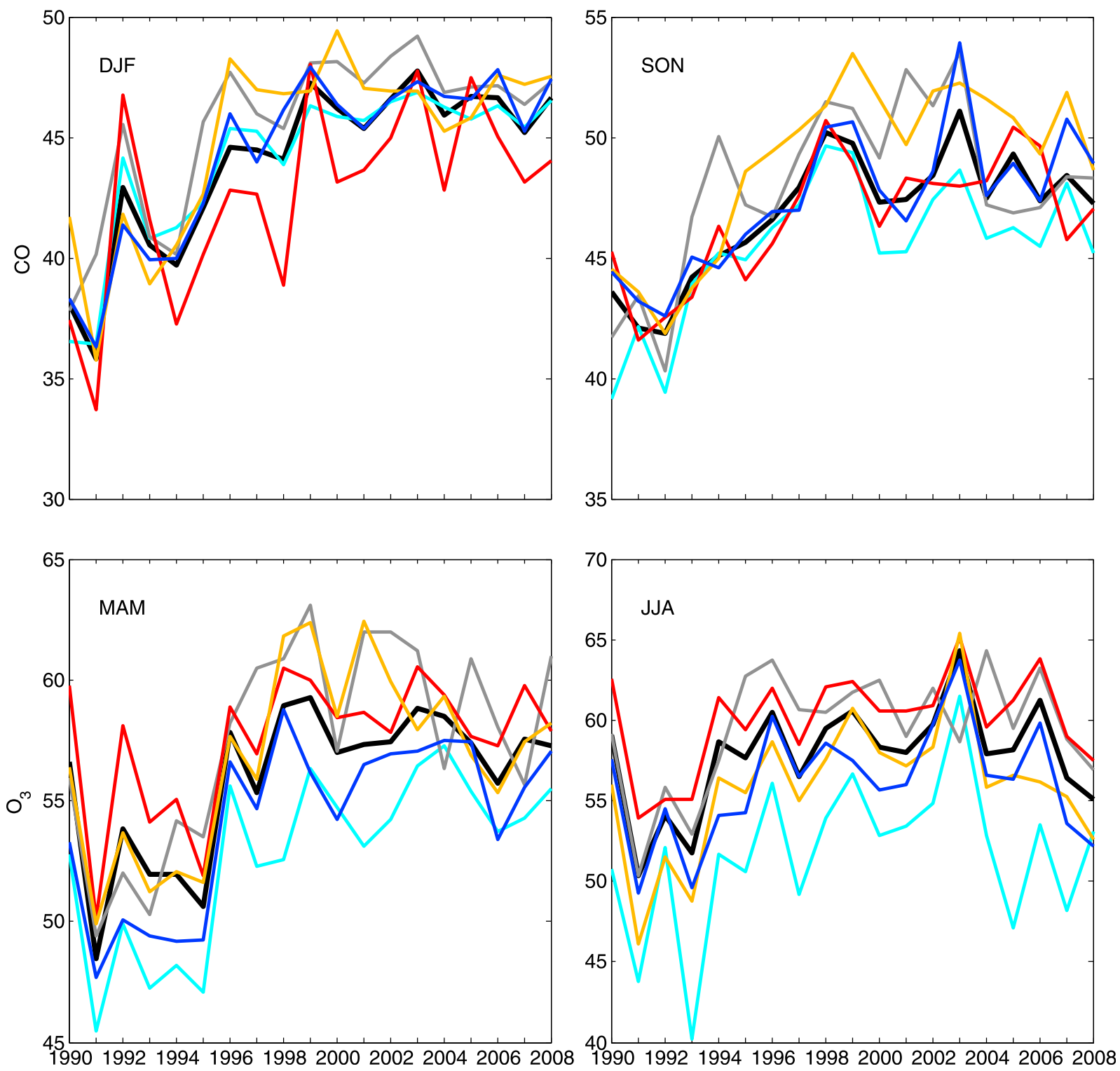

Figure 10. Interannual changes in mean ozone concentrations for individual source regions for Jungfraujoch. Lines: total data set (black); European PBL (red); free troposphere (blue); North American PBL (yellow); marine boundary layer (sky blue); and stratosphere (dark grey).

and European PBL were the two main air masses arriving at JFJ. In winter, air masses coming from MBL contributed in a comparable frequency with FT and European PBL air masses (only for about $5 \%$ in summer).

[24] Statistical tests of monthly mean ozone concentrations (using Mann-Whitney-U test) showed significant separation among the individual classes (not shown). However, The changes of ozone mean concentrations in all source regions followed very similar patterns, which complicates the quantitative estimation of individual contributions to overall ozone changes at JFJ (see Figure 10). We note that the interannual variations of ozone mean concentrations for the period of 1990-2008 for the air masses coming from the individual source regions was large. In spring and summer, air masses having recent contact with European PBL showed relatively high ozone concentrations because of the enhanced photo- chemical ozone production. FT air masses showed very similar ozone concentrations as compared to the entire data in winter and autumn, while evidently lower values were observed in spring and summer.

\section{Conclusions and Discussion}

[25] An overall upward ozone trend with a seasonal maximum of $0.99 \pm 0.46 \mathrm{ppb} / \mathrm{yr}$ in winter and a seasonal minimum of $0.69 \pm 0.80 \mathrm{ppb} / \mathrm{yr}$ in summer was documented at Jungfraujoch (JFJ), Switzerland in the period of 1990 1999 , followed by a period without significant changes. The ozone evolution was influenced by particular atmospheric conditions: (1) a negative anomaly in 1992-1993 coincident with the large volcanic eruption of Mount Pinatubo; (2) a positive anomaly in 1997-1998, which was explained by 
numerical simulations as a special interplay of particular dynamic conditions also allowing for air transport from Asia and Siberia where large biomass burning occurred [Koumoutsaris et al., 2008], though high ozone values in 1999 remain unexplained; (3) another positive anomaly in summer 2003 coinciding with the record-breaking Europeanscale heat wave. Quantitatively, the 1992-1993 anomaly had the largest impact on the trends and, for instance, affected the trend in winter by about $8 \%$. The ozone increase at JFJ provides evidence for increase in baseline ozone, since JFJ is exposed to free tropospheric condition most of the time (for instance $79 \%$ of the time in winter during 1990-2008 according to our trajectory analysis).

[26] To further investigate the trends, a method based on 20 day backward trajectories of air masses arriving at JFJ was developed to classify measurements into baseline air and air with recent contact to the European PBL. A good agreement between trajectory-selected European $\mathrm{CO}$ and free tropospheric CO measurements derived from the MOZAIC project confirms the trajectory-based classification. Further support was provided by using a meteorological filter, which distinguishes different weather situations, and matches reasonably well with the classification derived by trajectories, particularly in winter.

[27] According to the origin of the air mass, data within the baseline air class were further classified into subsets, and analyzed regarding ozone concentrations and their changes. Ozone concentrations derived for the individual air mass categories were plausible with respect to the recent history of the air masses (e.g., air masses with recent contact with the stratosphere showed enhanced ozone), but ozone concentrations of the different classes did not show significantly different concentrations. Positive trends were found in each source category although with different magnitude, which complicates the quantitative attribution of ozone changes at JFJ to individual source regions. The European PBL air showed increasing ozone concentrations in winter, attributable to decreasing NO emissions and therefore decreasing ozone titration. For summer, the ozone increase in European PBL air was relatively small probably reflecting decreasing European ozone precursor emissions balanced by increasing baseline ozone.

[28] It is well established that in (most) EU-15 countries ozone precursor emissions strongly decreased particularly during the 1990s when ozone concentrations strongly increased at JFJ. A marked upward trend in $\mathrm{NO}_{\mathrm{x}}$ emissions from international shipping was reported (Endresen et al. [2003] found $1.6 \% / y r$ increase in fuel consumption from shipping between 1996 and 2000 and Dalsøren et al. [2010] estimated an increase of $33 \%$ in global ship emissions over the period 2000-2007). However, we did not find evidence that the ship emissions over the North Atlantic substantially contributed to the upward baseline ozone trend at JFJ. Anthropogenic ozone precursors decreased in North America, particularly during the most recent years and therefore they hardly can explain increasing ozone concentrations at JFJ. Satellite observations indicate that $\mathrm{NO}_{\mathrm{x}}$ emissions strongly increased in South East Asia [e.g., Richter et al., 2005]. Our data analysis does not provide any evidence for a substantial contribution of Asian emissions at the location at JFJ. If Asian emission increase would substantially contribute to the measured ozone increase at JFJ, a continued increase after around 2000 would have been expected because the South East Asian emission increase did not stabilize after 2000.

[29] The similarity of ozone changes within the different classes suggests a cause which is outside the time horizon of 20 days prior to arrival at JFJ. Changes in global $\mathrm{OH}$ concentration can be excluded as potential cause for ozone changes at JFJ because of its very small interannual variability as documented recently by Montzka et al. [2011]. The methane lifetime is much longer than 20 days, the length of the back trajectories in this study and therefore changes in methane concentrations could be considered as a possible driver for ozone changes. However, the results of global numerical simulations presented by Koumoutsaris et al. [2008] include the change of methane concentrations, but they found large discrepancies between numerical simulations and ozone measurements in the years following the Mount Pinatubo eruption. This suggests a major role of the modulation of the stratospheric ozone source, since presentday global Eulerian transport models are hardly capable to describe the variability in stratospheric downward flux of ozone in an adequate way. No separation between ozone trends of stratospherically influenced and purely tropospheric air masses was observed in our study. Therefore, our results do not support the study of Ordónez et al. [2007], in which a major role of modulation of injection of stratospheric ozone was postulated. However, we believe that an adequate description of the effect of changes in the source strength of stratospheric ozone is also difficult for single trajectory analysis, since air parcels of stratospheric origin tend to be strongly mixed with tropospheric air prior to arrival at JFJ. We therefore think that the use of more advanced techniques such as domain filling trajectories might be most promising to show whether the variable injection of ozone from the stratosphere might be a significant cause for the ozone increase at JFJ in the 1990s, particularly because ozone concentrations in the lower-most stratosphere were rather stable since 2000 in contrast to the 1990 s.

[30] Acknowledgments. J. Cui was supported by a research grant of ETH Zürich, and S. Pandey Deolal was supported by a grant of the Swiss National Science Foundation (SNF). S. Henne was supported by the GEOmon (Global Earth Observation and Monitoring) Integrated Project under the 6th Framework Program of the The European Commission (contract FP6-2005-Global-4-036677). Thanks go to the MOZAIC team for making their data available. The authors also would like to gratefully acknowledge the support of the MOZAIC program by the European Communities, EADS, Airbus, and the airlines Lufthansa, Austrian, and Air France, who have carried the MOZAIC equipment free of charge since 1994. Access to the ERA-Interim data was provided by the Swiss National Weather Service (MeteoSwiss). The Swiss National Air Pollution Monitoring Network is run by Empa in joint collaboration with the Swiss Federal Office for the Environment. We thank the International Foundation High Altitude Research Station Jungfraujoch and Gornergrat (HFSJG) for access to Jungfraujoch facilities. We also acknowledge the valuable help of $\mathrm{H}$. Rieder and J. Mäder for statistical analysis.

\section{References}

Angell, J. (1997), Estimated impact of Agung, El Chichon and Pinatubo volcanic eruptions on global and regional total ozone after adjustment for the QBO, Geophys. Res. Lett., 24(6), 647-650, doi:10.1029/97GL00544.

Auvray, M., and I. Bey (2005), Long-range transport to Europe: Seasonal variations and implications for the European ozone budget, J. Geophys. Res., 110, D11303, doi:10.1029/2004JD005503. 
Balzani Lööv, J., S. Henne, G. Legreid, J. Staehelin, S. Reimann, A. S. H. Prévôt, M. Steinbacher, and M. Vollmer (2008), Estimation of background concentrations of trace gases at the Swiss Alpine site Jungfraujoch (3580 m asl), J. Geophys. Res., 113, D22305, doi:10.1029/ 2007JD009751.

Berrisford, P., D. Dee, K. Fielding, M. Fuentes, P. Kallberg, S. Kobayashi, and S. Uppala (2009), The ERA-Interim Archive, ERA Rep. Ser. 1, ECMWF, Reading, U. K

Brönnimann, S., B. Buchmann, B. Schwarzenbach, and H. Wanner (2000), Ozonmessungen im Schweizer NABEL-Mess-netz: Datenkontrolle, Homogenität und Trends, in Troposphärisches Ozon, vol. 32, pp. 395-400, KRdL-Schriftenreihe, Düsseldorf, Germany.

Brönnimann, S., B. Buchmann, and H. Wanner (2002), Trends in near-surface ozone concentrations in Switzerland: The 1990s, Atmos. Environ., 36, 2841-2852.

Cooper, O., et al. (2010), Increasing springtime ozone mixing ratios in the free troposphere over western North America, Nature, 463, 344-348, doi:10.1038/nature 08708 .

Crutzen, P. (1974), Photochemical reactions initiated by and influencing ozone in the unpolluted troposphere, Tellus, 26, 47-57.

Cui, J., M. Sprenger, J. Staehelin, A. Siegrist, M. Kunz, S. Henne, and M. Steinbacher (2009), Impact of stratospheric intrusions and intercontinental transport on ozone at Jungfraujoch in 2005: Comparison and validation of two Lagrangian approaches, Atmos. Chem. Phys., 9, 3371-3383

Dalsøren, S. B., M. S. Eide, G. Myhre, Ø. Endresen, I. A. Isaksen, and J. S. Fuglestvedt (2010), Impacts of the large increase in international ship traffic 2000-2007 on tropospheric ozone and methane, Environ. Sci. Technol., 44, 2482-2489.

Danielsen, E. (1968), Stratospheric-tropospheric exchange based on radioactivity ozone and potential vorticity, J. Atmos. Sci., 25, 502-518.

Derwent, R., M. Jenkin, S. Saunders, M. Pilling, P. Simmonds, N. Passant, G. Dollard, P. Dumitrean, and A. Kent (2003), Photochemical ozone formation in north west Europe and its control, Atmos. Environ., 37, 1983-1991.

Endresen, Ø., E. Sørgård, J. Sundet, S. Dalsøren, I. Isaksen, T. Berglen, and G. Gravir (2003), Emission from international sea transportation and environmental impact, J. Geophys. Res., 108(D17), 4560, doi:10.1029/ 2002JD002898.

European Environment Agency (EEA) (2010), European Union emission inventory report 1990-2008 under the UNECE Convention on Longrange Transboundary Air Pollution (LRTAP), report, Copenhagen. (Available at http://www.eea.europa.eu/publications/european-unionemission-inventory-report.)

Gilge, S., C. Plass-Duelmer, W. Fricke, A. Kaiser, L. Ries, B. Buchmann, and M. Steinbacher (2010), Ozone, carbon monoxide and nitrogen oxides time series at four alpine GAW mountain stations in central Europe, Atmos. Chem. Phys., 10, 12,295-12,316.

Henne, S., J. Dommen, B. Neininger, S. Reimann, J. Staehelin, and A. S. H. Prévôt (2005), Influence of mountain venting in the Alps on the ozone chemistry of the lower free troposphere and the European pollution export, J. Geophys. Res., 110, D22307, doi:10.1029/2005JD005936.

Henne, S., D. Brunner, D. Folini, S. Solberg, J. Klausen, and B. Buchmann (2010), Assessment of parameters describing representativeness of air quality in-situ measurement sites, Atmos. Chem. Phys., 10, 3561-3581.

Huntrieser, H., et al. (2005), Intercontinental air pollution transport from North America to Europe: Experimental evidence from airborne measurements and surface observations, J. Geophys. Res., 110, D01305, doi:10.1029/2004JD005045.

Jaffe, D., and J. Ray (2007), Increase in surface ozone at rural sites in the western US, Atmos. Environ, 41, 5452-5463.

Junge, C. (1962), Global ozone budget and exchange between stratosphere and troposphere, Tellus, 14, 363-377.

Koumoutsaris, S., I. Bey, S. Generoso, and V. Thouret (2008), Influence of El Niño-Southern Oscillation on the interannual variability of tropospheric ozone in the northern midlatitudes, J. Geophys. Res., 113, D19301, doi:10.1029/2007JD009753.

Kuebler, J., H. Van Den Bergh, and A. Russell (2001), Long-term trends of primary and secondary pollutant concentrations in Switzerland and their response to emission controls and economic changes, Atmos. Environ., $35,1351-1363$

Lefohn, A. S., D. Shadwich, and S. J. Oltmans (2010), Characterizing changes of surface ozone levels in metropolitan and rural areas in the United States for 1980-2008 and 1994-2008, Atmos. Environ., 244, 5199-5210

Levy, H. (1971), Normal atmosphere: Large radical and formaldehyde concentrations predicted, Science, 173, 141-143.
Li, Y., M. Campana, S. Reimann, D. Schaub, K. Stemmler, J. Staehelin, and T. Peter (2005), Hydrocarbon concentrations at the Alpine mountain sites Jungfraujoch and Arosa, Atmos. Environ., 39, 1113-1127.

Lindskog, A., M. Beekmann, P. Monks, M. Roemer, E. Schuepbach, and S. Solberg (2001), Tropospheric Ozone Research in Annual Report 2000, technical report, Natl. Res. Cent. For Environ. and Health, Munich, Germany.

Logan, J. (1994), Trends in the vertical distribution of ozone: An analysis of ozonesonde data, J. Geophys. Res., 99(D12), 25,553-25,585, doi:10.1029/94JD02333.

Logan, J., et al. (1999), Trends in the vertical distribution of ozone: A comparison of two analyses of ozonesonde data, J. Geophys. Res., 104(D21), 26,373-26,399, doi:10.1029/1999JD900300.

Montzka, S. A., M. Krol, E. Dlugokencky, B. Hall, P. Jöckel, and J. Lelieveld (2011), Small interannual variability of global atmospheric hydroxyl, Science, 331, 67-69, doi:10.1126/science.1197640.

Oltmans, S., et al. (1998), Trends of ozone in the troposphere, Geophys. Res. Lett., 25(2), 139-142, doi:10.1029/97GL03505.

Oltmans, S., et al. (2006), Long-term changes in tropospheric ozone, Atmos. Environ., 40, 3156-3173.

Ordóñez, C. (2006), Trend analysis of ozone and evaluation of nitrogen dioxide satellite data in the troposphere over Europe, Ph.D. thesis, ETH Zürich, Zürich, Switzerland.

Ordóñez, C., H. Mathis, S. Henne, C. Hüglin, J. Staehelin, and A. S. H. Prévôt (2005), Changes of daily surface ozone maxima in Switzerland in all seasons from 1992 to 2002 and discussion of summer 2003, Atmos. Chem. Phys., 5, 1187-1203.

Ordóñez, C., D. Brunner, J. Staehelin, P. Hadjinicolaou, J. Pyle, M. Jonas, H. Wernli, and A. Prévôt (2007), Strong influence of lowermost stratospheric ozone on lower tropospheric background ozone changes over Europe, Geophys. Res. Lett., 34, L07805, doi:10.1029/2006GL029113.

Parrish, D., D. Millet, and A. Goldstein (2009), Increasing ozone in marine boundary layer air inflow at the west coasts of North America and Europe, Atmos. Chem. Phys., 9, 1303-1323.

Pochanart, P., H. Akimoto, S. Maksyutov, and J. Staehelin (2001), Surface ozone at the Swiss Alpine site Arosa: The hemispheric background and the influence of large-scale anthropogenic emissions, Atmos. Environ., $35,5553-5566$.

Richter, A., J. Burrows, H. Nüss, C. Granier, and U. Niemeier (2005), Increase in tropospheric nitrogen dioxide over china observed from space, Nature, 437, 129-132, doi:10.1038/nature04092.

Staehelin, J., J. Thudium, R. Buehler, A. Volz-Thomas, and W. Graber (1994), Trends in surface ozone concentration at Arosa (Switzerland), Atmos. Environ., 28, 75-87.

Staehelin, J., N. Harris, C. Appenzeller, and J. Eberhard (2001), Ozone trends: A review, Rev. Geophys., 39(2), 231-290, doi:10.1029/1999RG000059.

Stohl, A., and T. Trickl (1999), A textbook example of long-range transport: Simultaneous observation of ozone maxima of stratospheric and North American origin in the free troposphere over Europe, J. Geophys. Res., 104(D23), 30,445-30,462, doi:10.1029/1999JD900803.

Streets, D. G., N. Y. Tsai, H. Akimoto, and K. Oka (2001), Trends in emissions of acidifying species in Asia, Water Air Soil Pollut., 130, 187-192.

Tarasova, O., I. Senik, M. Sosonkin, J. Cui, J. Staehelin, and A. Prévôt (2009), Surface ozone at the Caucasian site Kislovodsk High Mountain Station and the Swiss Alpine site Jungfaujoch: Data analysis and trends (1990-2006), Atmos. Chem. Phys., 9, 4157-4175.

Thouret, V., J.-P. Cammas, B. Sauvage, G. Athier, R. Zbinden, P. Nédélec, P. Simon, and F. Karcher (2006), Tropopause referenced ozone climatology and inter-annual variability (1994-2003) from the MOZAIC programme, Atmos. Chem. Phys., 6, 1033-1051.

TOR-2 (2003), Tropospheric ozone reseach: EUROTRAC-2 subproject final report, report, ISS GSF Natl. Res. Cent. for Environ. and Health, Munich, Germany.

U.S. Environmental Protection Agency (2009), Air Quality Trends, report, Research Triangle Park, N. C. (Available at http://www.epa.gov/ airtrends/aqtrends.html.)

Vingarzan, R. (2004), A review of surface ozone background levels and trends, Atmos. Environ., 38, 3431-3442.

Wernli, H., and H. Davies (1997), A Lagrangian-based analysis of extratropical cyclones. I: The method and some applications, Q. J. R. Meteorol. Soc., 123, 467-489.

World Meteorological Organization (2003), Scientific Assessment of Ozone Depletion: 2002, Global Ozone Res. Monit. Proj. Rep. 47, Geneva, Switzerland.

Zanis, P., E. Schuepbach, H. Scheel, M. Baudenbacher, and B. Buchmann (1999), Inhomogeneity and trends in the surface ozone record (1988-1996) at Jungfraujoch in the Swiss Alps, Atmos. Environ., 33, 3777-3786. 
Zanis, P., A. Ganser, C. Zellweger, S. Henne, M. Steinbacher, and J. Staehelin (2007), Seasonal variability of measured ozone production efficiencies in the lower free troposphere of central Europe, Atmos. Chem. Phys., 7, 223-236. Zbinden, R. M., J.-P. Cammas, V. Thouret, P. Nédélec, F. Karcher, and P. Simon (2006), Mid-latitude tropospheric ozone columns from the MOZAIC program: Climatology and interannual variability, Atmos. Chem. Phys., 6, 1053-1073.

Zellweger, C., M. Ammann, B. Buchmann, P. Hofer, M. Lugauer, R. Rüttimann, N. Streit, E. Weingartner, and U. Baltensperger (2000) Summertime $\mathrm{NO}_{\mathrm{y}}$ speciation at the Jungfraujoch, $3580 \mathrm{~m}$ above sea level, Switzerland, J. Geophys. Res., 105(D5), 6655-6667, doi:10.1029/ 1999JD901126.

Zellweger, C., J. Forrer, P. Hofer, S. Nyeki, B. Schwarzenbach, E. Weingartner, M. Ammann, and U. Baltensperger (2003), Partitioning of reactive nitrogen $\left(\mathrm{NO}_{\mathrm{y}}\right)$ and dependence on meteorological conditions in the lower free troposphere, Atmos. Chem. Phys., 3, 779-796.
Zhang, Q., et al. (2007), $\mathrm{NO}_{\mathrm{x}}$ emision trends for China, 1995-2004: The view from the ground and the view from space, J. Geophys. Res., 112, D22306, doi:10.1029/2007JD008684.

J. Cui, S. Pandey Deolal, M. Sprenger, and J. Staehelin, Institute for Atmospheric and Climate Science, ETH Zürich, CH-8092 Zürich, Switzerland. (junbo.cui@env.ethz.ch; shubha.pandey@env.ethz.ch; michael.sprenger@env.ethz.ch; Johannes.Staehelin@env.ethz.ch)

S. Henne and M. Steinbacher, Empa, Swiss Federal Laboratories for Materials Science and Technology, CH-8600 Dübendorf, Switzerland. (stephan.henne@empa.ch; martin.steinbacher@empa.ch)

P. Nédélec, Laboratoire d'Aérologie, Centre National de la Recherche Scientifique, F-31055 Toulouse, France. (philippe.nedelec@aero.obs-mip.fr) 